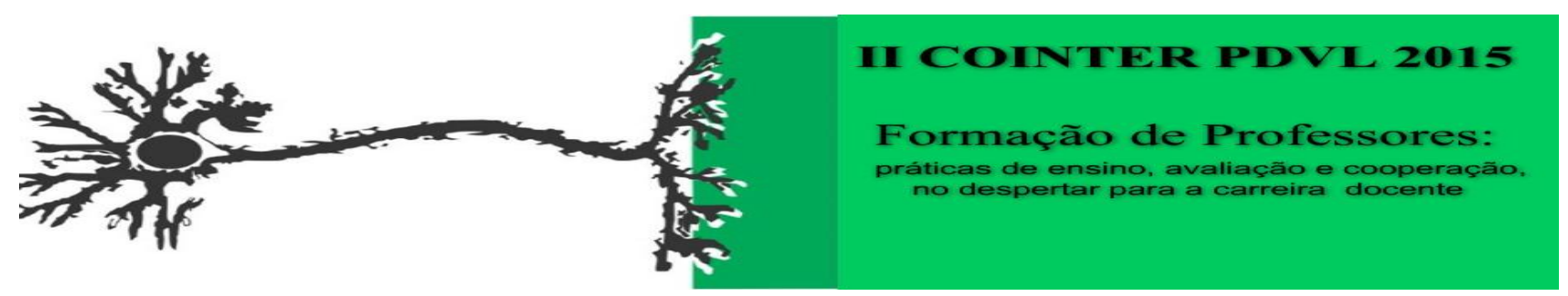

\title{
UMA EXPERIÊNCIA DO PIBID GEOGRAFIA DA ESCOLA ESTADUAL PROF. FRANCISCO IVO CAVALCANTI EM NATAL/RN NAS ÁGUAS DO RIO POTENGI
}

Apresentação: Relato de Experiência

\author{
Laís Rodrigues Alves ${ }^{1}$; Lourdes Caroline Pereira da Silva ${ }^{2}$; Kallyanny Raissa Silva Santos ${ }^{3}$; \\ Maria Cristina Cavalcanti Araújo ${ }^{4}$
}

\section{Introdução}

O presente relato refere-se a uma experiência realizada com alunos da $1^{\circ}$ série do ensino médio da Escola Estadual Professor Francisco Ivo Cavalcanti, localizada no município de Natal/RN. A aula de campo foi realizada no dia 14/04/2015 através da atuação do Programa Institucional de Bolsa de Iniciação à Docência - PIBID, subprojeto de Geografia do Instituto Federal de Educação, Ciência e Tecnologia do Rio Grande do Norte, campus Natal Central. O programa tem como objetivo geral contribuir para a formação do licenciando através das práticas realizadas nas escolas da rede pública de ensino.

\section{Relato de Experiência}

A aula de campo foi realizada no estuário do Rio Potengi, que banha a capital do estado do Rio Grande do Norte, através do Projeto Barco Escola Chama Maré, desenvolvido pelo governo do estado, por meio do Instituto de Desenvolvimento Sustentável e Meio Ambiente - IDEMA, visando a educação ambiental.

A atividade teve como objetivo trabalhar a educação ambiental, proporcionar o reconhecimento do ecossistema manguezal, sua importância e necessidade de preservação, fazendo assim uma relação com os conteúdos geográficos ministrados na sala de aula, além de buscar a interdisciplinaridade, trabalhando na perspectiva das disciplinas de História, Geografia e Biologia.

A problemática consiste na poluição do Rio Potengi através do lixo proveniente de indústrias, comércio e da própria população. Sendo assim, a metodologia utilizada foi o estudo do meio, na qual os alunos relacionaram a teoria com a vivência. Portanto o estudo do meio:

É uma técnica de grande importância, pois é através dela que se leva o aluno a tomar

\footnotetext{
${ }^{1}$ Licenciatura em Geografia, IFRN-Campus Natal Central, laisalvesIra@hotmail.com

${ }^{2}$ Licenciatura em Geografia, IFRN-Campus Natal Central, carolinesilvah1@hotmail.com

${ }^{3}$ Licenciatura em Geografia, IFRN-Campus Natal Central, kallyannysantos@outlook.com

${ }^{4}$ Doutora em Recursos Naturais, IFRN-Campus Natal Central, cristina.cavalcanti@ifrn.edu.br
} 
contato com o complexo vivo, com um conjunto significativo que é o próprio meio, onde natureza e cultura se interpenetram. (Balzan, 1969, p. 106 apud Feltran, 2005, p. 119)

Deste modo a atividade ocorreu a bordo de uma embarcação do tipo catamarã, que partiu do Iate Club de Natal no sentido Fortaleza dos Reis Magos / Boca da Barra, passando pela Redinha e Cemitério dos Ingleses, entrando na gamboa Jaguaribe e seguindo na direção da Ponte Ferroviária de Igapó, voltando pela Base Naval e Porto de Natal, chegando ao local do embarque.

Imagem 1: Aula Campo Barco Escola Chama Maré

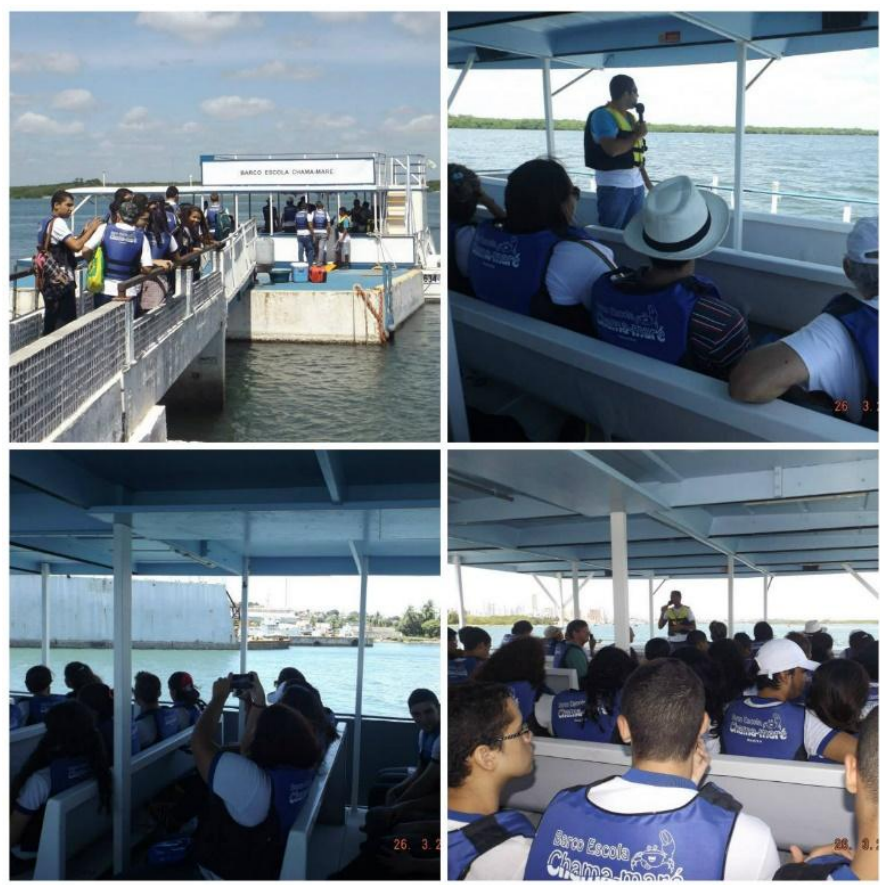

\section{Considerações}

Através da experiência verificou-se a importância do estudo do meio para o ensino de Geografia, uma vez que a técnica permite ao discente o contato direto com a situação problema. Desta forma, o aluno torna-se um agente ativo no processo de ensino - aprendizagem.

\section{Referência}

VEIGA, Ilma Passos Alencastro. Técnicas de Ensino: Por que não?. Campinas, Sp Papirus, 1991 (Coleção Magistério: Formação e Trabalho Pedagógico), ed 16 . Cap 1, p. 115 $-128$.

BRASIL. Instituto de Desenvolvimento Sustentável e Meio Ambiente. Disponível em <http:/ / www.idema.rn.gov.br/Conteudo.asp?TRAN=ITEM\&TARG=351\&ACT=\&PAGE $=\& P A R M=\& L B L=$ Projetos $>$. Acesso em 05 de julho 2015 . 